\title{
PEMBIASAN REVOLUSI PENGETAHUAN: PEMIKIRAN KUHN DAN REFLEKSI SEJARAH KEHIDUPAN PROF. DUDUNG DARUSMAN
}

(Refraction of Knowledge Revolution: Kuhn's Thought and Reflection of Prof. Dudung Darusman's Life History)

\author{
Handoyo \\ Pusat Penelitian dan Pengembangan Sosial, Ekonomi, Kebijakan dan Perubahan Iklim. \\ Badan Litbang dan Inovasi, Kementerian Lingkungan Hidup dan Kehutanan. \\ Jl. Gunung Batu No. 5 Bogor 16118 Indonesia. \\ E-mail: handoyoasterian20@yahoo.com
}

Diterima 26 April 2017, direvisi 26 Oktober 2017, disetujui 22 November 2017.

\begin{abstract}
Most of the literature related to the development of forestry science in Indonesia explains that there has been a shift in the forest management paradigm from timber-based forest supremacy management paradigm to community-based forest management paradigm. This paper aims to argue that it is biased scientifically. This paper is presented based on research by using narrative approach and analysis of Dudung Darusman life history, that shows that the process of shifting attention to civil/communal supremacy over common property, and seeking justification for the community-based forest management perspective as a paradigm, can not be called as knowledge revolution that which lead to paradigm shift. The orchestration of particular political and power practices as well as their manifestations in the more paradigmatically external national forest management are responsible for the refraction.
\end{abstract}

Keywords: Paradigm shift; narrative approach; scientific revolution.

\begin{abstract}
ABSTRAK
Sebagian besar literatur terkait perkembangan ilmu pengetahuan kehutanan di Indonesia menjelaskan bahwa telah terjadi pergeseran paradigma pengelolaan hutan. Paradigma pengelolaan hutan berbasis supremasi hasil kayu berpindah kepada paradigma pengelolaan hutan berbasis komunitas. Tulisan ini bertujuan memberikan argumen bahwa hal tersebut bias secara ilmiah. Tulisan yang didasarkan pada penelitian yang menggunakan pendekatan naratif dan analisis sejarah kehidupan Dudung Darusman ini, menunjukkan bahwa proses perpindahan perhatian pada supremasi sipil/komunal atas common property dan pencarian pembenaran atas perspektif community-based forest management sebagai sebuah paradigma tidak dapat disebut sebagai revolusi pengetahuan yang berujung pada pergeseran paradigma. Tulisan ini juga memperlihatkan bahwa orkestrasi praktik kekuasaan dan politik yang partikular serta manifestasinya dalam pengelolaan hutan nasional yang lebih bersifat eksternal paradigmatik bertanggung jawab atas pembiasan tersebut.
\end{abstract}

Kata kunci: Pergeseran paradigma; pendekatan naratif; revolusi pengetahuan. 


\section{PENDAHULUAN}

Titik masuk penelitian ini adalah tesis yang ditawarkan oleh Thomas Kuhn dalam The Structure of Scientific Revolution tentang pergeseran paradigma dalam revolusi ilmu pengetahuan. Ide kunci Kuhn dalam karya besarnya tersebut adalah revolusi ilmu pengetahuan dari apa yang disebut Kuhn sebagai "normal science" yaitu pengetahuan di mana permasalahan atau fenomena baru yang muncul di dalamnya masih dapat dijelaskan oleh paradigma yang berlaku, ke pengetahuan dengan paradigma yang baru karena masalah-masalah atau fenomenafenomena yang timbul di dalam pengetahuan sudah tidak dapat dijelaskan oleh paradigma lama. Dalam The Structure of Scientific Revolution yang kompleks tersebut Thomas Kuhn sebenarnya tidak secara konsisten menggunakan terminologi paradigma. Banyak ilmuwan yang menginterpretasikan sebagai paradigma ketika Kuhn menyebut teori dalam karya besarnya itu (Purtill, 1967). Ada permasalahan dalam paradigma tersebut ketika menghadapi masalah atau fenomena dalam pengetahuan yang menyebabkan paradigma tersebut harus diganti dengan yang baru sehingga dapat menjawab dan menjelaskan permasalahan-permasalahan atau fenomena baru di dalam pengetahuan. Pada konteks pengetahuan ilmu kehutanan, analis dan praktisi pada berbagai literatur selalu menyebutkan adanya pergeseran paradigma pada lapangan manajemen hutan di Indonesia (Michon, De Foresta, Levang, \& Verdeaux, 2007; Roshetko, Snelder, Lasco, \& Van Noordwijk, 2008; van Noordwijk, Mulyoutami, Sakuntaladewi, \& Agus, 2008). Paradigma yang mendasari pengetahuan pengelolaan hutan di Indonesia telah bergeser. Meminjam istilah Nancy Peluso, scientific forestry (Peluso, 1994) yang merupakan inti dari diskursus pengetahuan kehutanan timberbased forest management telah tergantikan oleh sebagian pengetahuan berdiskursus community-based forest management.
Struktur dan ideologi pengelolaan hutan "ilmiah" (scientific forestry) yang berasal dari Jerman datang ke Jawa pada abad ke-19 direproduksi dalam suasana kolonial. Rimbawan kolonial maupun kontemporer mendefinisikan manajemen ilmiah sebagai pengelolaan yang dilakukan dengan ketaatan sistematis terhadap rencana kerja dalam penebangan dan penanaman kembali hutan (dalam perkebunan hutan) sesuai kaidahkaidah teknologi pengelolaan tanah hutan (silvikultur) yang dikembangkan melalui eksperimentasi dari waktu ke waktu. Pergeseran ini telah menjadi perdebatan panjang ketika para penganut historicist relativism melihat pengetahuan secara historis tidak muncul begitu saja dengan sendirinya namun pengetahuan dikonstruksi secara sosial oleh karenanya bersifat konvensional yang merefleksikan struktur-struktur obyektif dan keyakinan dari suatu semesta sosial yang khas (Bourdieu, 1991).

Tawaran Kuhn dan Bordieau dapat dijadikan titik pandang yang berbeda dalam memahami panorama pergeseran pengetahuan kehutanan tersebut di atas. Penelitian ini memediasi subyektifitas seorang Dudung Darusman, profesor dan guru besar pada Fakultas Kehutanan Institut Pertanian Bogor (IPB) tentang revolusi pengetahuan kehutanan di Indonesia.

\section{METODE PENELITIAN}

Dokumentasi sejarah kehidupan (life history documentation) dan pendekatan naratif (narrative approaches) muncul kembali pada area studi sosial pada dekade terakhir, sebagai bagian dari strategi koleksi data penelitian sosial kualitatif (Creswell \& Poth, 2017; Flick, 2014). Kedua alat pendekatan ini biasa digunakan oleh para peneliti sosial untuk memberi tawaran yang menarik dalam menghubungkan sejarah dan cerita dari individu untuk memahami fenomena manusia dan sosial yang lebih luas. 
Namun masih banyak yang mempertanyakan mengenai validitas kedua pendekatan tersebut. Pertanyaan yang mungkin paling banyak dilontarkan kepada peneliti sosial yang sering menggunakan alat ini adalah apa perbedaan dari kedua strategi koleksi data tersebut? Apa yang membedakan kedua strategi tersebut dengan jenis strategi penelitian kualitatif yang lainnya? Atau pertanyaan yang mungkin lebih luas adalah apa hubungan dari kedua strategi tersebut dengan orientasi post strukturalisme?

Pada praktiknya, kedua strategi tersebut tidak mempunyai perbedaan yang signifikan ketika keduanya dilihat sebagai metode yang mencoba meruntuhkan dinding sekat antropologi, sosiologi, studi sejarah dan studi linguistik. Kedua pendekatan mempunyai subyek yang sama yaitu cerita/sejarah, bersandar pada subyektivitas dan pemaknaan yang dikonstruksi oleh individu-individu pada situasi tertentu/pengalaman tertentu sehingga pengalaman tersebut secara rasional tidak mudah dipisah-pisahkan ke dalam kompartemen-kompartemen disiplin ilmu. Alat-alat tersebut mengasumsikan kehidupan masa lalu yang dinamis dan terbuka untuk diinterpretasi maupun diinterpretasi ulang ke dalam pemaknaan untuk kehidupan kekinian.

Metode ini pertama kembali berkembang di kalangan peneliti sosial di Amerika Serikat di mana untuk alat ini pertama kali digunakan untuk mewawancarai pemimpin penduduk asli Amerika. Ketika itu, alat ini digunakan untuk mendapatkan gambaran bagaimana kehidupan mereka dan bagaimana rasanya menjadi mereka (informan). Secara spesifik, alat ini digunakan untuk mendapatkan gambaran bagaimana hidup/cara hidup (way of life) mereka menghilang dari kehidupan sosial Amerika (Bertaux, 1981). Metode ini banyak digunakan oleh para antropolog psikologi yang sering disebut dengan istilah individual life history. Data yang dikumpulkan dalam penelitian dengan metode ini adalah semua keterangan mengenai apa yang pernah dialami individu-individu tertentu sebagai warga dari suatu masyarakat yang sedang menjadi obyek penelitian (Campbell, 1999).

Beberapa peneliti telah memanfaatkan sejarah kehidupan untuk mengeksplorasi besarnya masalah sosial, misalnya individu yang menyimpang, dampak industri, kemiskinan, broken home. Karena kelangkaan informan sebagai subyek penelitian, seleksi dan prosedur sampling harus dirancang dengan hati-hati (Silverman, 2013). Di sisi lain, hubungan antara informan dan peneliti harus tidak memihak di mana peneliti berpikiran terbuka, percaya, jujur, tapi tidak terlibat secara emosional (Marshall \& Hurworth, 2009; Silverman, 2013).

Pada perkembangannya, metode ini digunakan untuk tujuan-tujuan penggambaran seperti 1) Bagaimana situasi suatu daerah pada saat tertentu; 2) Bagaimana subyek melihat kehidupan mereka sendiri; 3) Bagaimana masyarakat memandang subyek dalam hal konsekuensi sesuatu atas apa yang dilakukan oleh subyek. Metode ini terhubung kepada "aliran Chicago" yaitu studi yang dilakukan oleh W. I. Thomas dan Florian Znaniecki yang sengaja mempekerjakan imigran Polandia sebagai subyek tulisan. Metode ini pernah mengalami kemunduran ketika pendekatan kuantitatif mendapat tempat dan menjadi arus utama sosiologi Amerika ketika itu. Pada tahun 1970-an metode ini dibangun kembali oleh Daniel Bertaux dan Paul Thompson. Metode ini kemudian dengan cepat menyebar ke Jerman, Italia dan Finlandia (Chamberlayne, Bornat, \& Wengraf, 2000). Pada kenyataannya, metode life history selalu dihubungkan dan dekat sekali hubungannya dengan pendekatan naratif (narrative approach).

Penelitian ini memilih Dudung Darusman sebagai key informan bukan hanya karena sebagai salah seorang Guru Besar Tetap pada Fakultas Kehutanan IPB sejak tahun 1995, namun beliau sarat pengalaman melalui berbagai jabatan penting yang telah diemban diantaranya sebagai Dekan Fakultas Kehutanan IPB selama dua periode (periode 1989-1992 dan periode 1992-1996), 


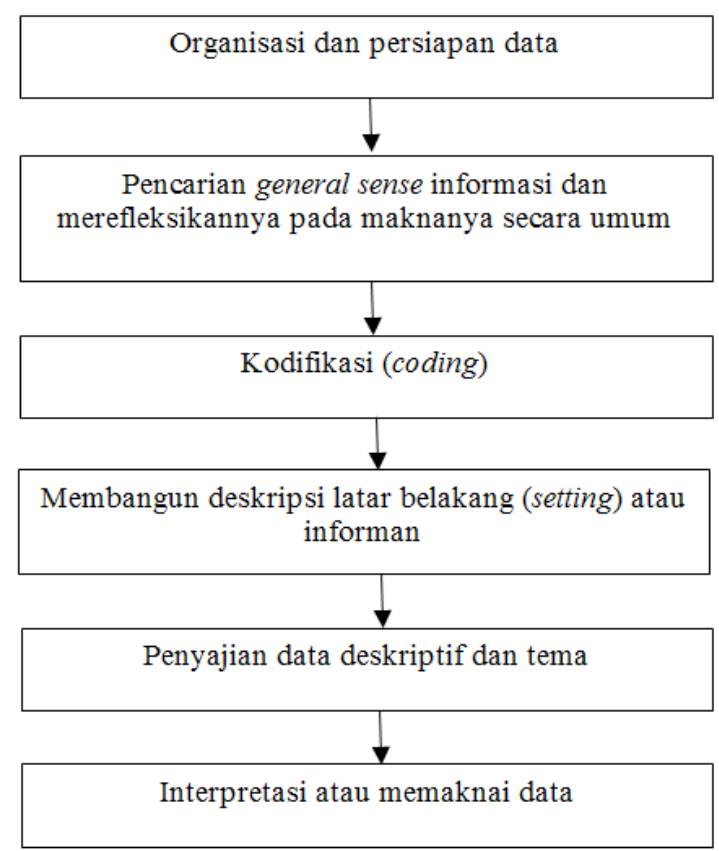

Sumber (Source): Creswell, 2003.

Gambar 1. Langkah analisis data

Figure 1. Data analysis steps

sebagai Ketua Lembaga Penelitian IPB tahun 1996-1999 dan sebagai Staf Ahli Menteri Kehutanan dan Perkebunan bidang Sosial dan Ekonomi pada tahun 1999. Penelitian ini menggunakan pendekatan naratif dan dokumentasi sejarah kehidupan. Strategi koleksi data untuk dokumentasi sejarah kehidupan adalah dengan teknik wawancara mendalam. Wawancara informan dilakukan dalam dua sesi pada bulan Januari 2008 di mana masing-masing sesi memakan waktu kurang lebih tiga jam. Wawancara dilakukan di ruang kerja Prof. Dudung Darusman di Kampus Fakultas Kehutanan Dramaga IPB Bogor. Analisis hasil dokumentasi dilakukan dengan kategorisasi tema Creswell.

Penarikan kesimpulan dilakukan melalui analisis dari triangulasi antara narasi perkembangan keilmuan kehutanan di Indonesia dan dokumen sejarah kehidupan Prof. Dudung Darusman serta perspektif revolusi keilmiahan tradisi Kuhnian.

\section{HASIL DAN PEMBAHASAN}

\section{A. Dudung Darusman Muda: "Ilmu Kehutanan Tidak Populer tapi Bermanfaat untuk Orang Banyak."}

Lahir 14 September tahun 1950 di Ciamis, Dudung Darusman yang telah dinobatkan sebagai Guru Besar di Fakultas Kehutanan IPB sejak tahun 1995 merupakan anak kedua dari enam bersaudara. Istri Dudung Darusman adalah Latifah Kosim di mana darinya mendapat dua orang putera Dani Hanifah (almarhum) dan Huda Salahudin. Kedua orang tuanya adalah Bapak Eman Sulaiman dan Ibu Ooh Sariah.

Masa kecil Dudung Darusman hingga remaja dihabiskan untuk bersekolah di Ciamis. Mulai dari tingkat SR (Sekolah Rakyat atau Sekolah Dasar saat ini) Negeri Cieurih (19561962), SMP (Sekolah Menengah Pertama) Negeri 1 Ciamis (1962-1965), SMA (Sekolah Menengah Atas) Negeri 1 Ciamis (1965-1968) semua dilampauinya sebagai yang terbaik. Setelah lulus SMA, di lingkungan orang Ciamis ketika itu ada istilah "ke Bandung" 
yang artinya menuntut ilmu ke luar wilayah Ciamis, ketika itu sekolah yang dianggap baik adalah Institut Teknologi Bandung (ITB) dan Fakultas Kedokteran Universitas Padjajaran (Unpad).

Dudung Darusman sempat ikut tes di ITB dan lulus, tetapi ketika melihat biaya yang harus dikeluarkan untuk kuliah di ITB sangat besar, maka dia memutuskan untuk tidak melanjutkan proses pendaftaran. Kemudian dia pulang ke Ciamis dan bertemu dengan saudaranya yang mengatakan "bila ingin sekolah dengan biaya murah masuklah ke Institut Pertanian Bogor (IPB)", sehingga motivasi utama Dudung Darusman masuk IPB adalah karena "murahnya". Motivasi yang kedua adalah IPB merupakan perguruan tinggi yang menggeluti ilmu pertanian yang kebetulan sama dengan pekerjaan orang tuanya saat itu.

Setelah masuk IPB, Dudung Darusman mendengar saran saudaranya yang mengatakan bila ingin lebih murah lagi dan bebas biaya praktik maka masuklah ke Fakultas Kehutanan. Karena berprestasi, Dudung Darusman muda dapat masuk ke IPB pada tahun 1969, di mana ketika itu ada sistem seleksi masuk IPB berdasarkan prestasi nilai rapor dan nilai ujian.

Ketika kuliahnya menginjak tingkat empat (telah mendapat sertifikat/gelar Sarjana Muda), dua adik kandung Dudung Darusman dari Ciamis datang ke Bogor untuk bersekolah di Bogor di mana yang satu memasuki jenjang perkuliahan dan yang lainnya pada jenjang SMA yang tentunya butuh biaya. Untuk membiayai sekolah kedua adiknya ini, Dudung Darusman mendaftarkan diri menjadi asisten dosen (golongan II/b) yang digaji sebesar Rp15.000,00 per bulan. Saat itu, dengan pendapatan sebesar itu, Dudung Darusman mampu membiayai semua adiknya. Tahun 1983, Dudung Darusman mendapat beasiswa United States Agency for International Development (USAID) pada kerja sama IPB dengan University of Wisconsin Amerika Serikat.
Lama kelamaan kecintaannya terhadap bidang kehutanan yang dulu dianggapnya tidak populer tetapi mempunyai banyak manfaat terpupuk sedemikian rupa, dan ketika Dudung Darusman menjadi yang terbaik pada tingkat tiga perkuliahan Dudung Darusman mendapat hadiah buku Ecology yang ditulis Eugene Odum yang membuatnya makin percaya bahwa ilmu kehutanan bermanfaat untuk banyak orang dan telah cocok dengan hati nuraninya.

Dudung Darusman sebenarnya telah tertarik dan mendalami bidang ekologi tetapi Herman Haeruman selaku dekan ketika itu memintanya untuk memberi kuliah ekonomi. Semenjak itu Dudung Darusman mengajar ekonomi yang menurutnya ekonomi tidak identik dengan "serakah". Dudung Darusman menganut ekonomi optimum, bukan ekonomi maksimum. Menurutnya yang membuat kehancuran bukanlah ilmu ekonomi tetapi "keserakahan". Menurutnya dimensi sosial dan politiklah yang menyebabkan orang menumpuk-numpuk kekayaan (kekayaan beda dengan barang yang dikonsumsi di mana orang tidak pernah puas untuk menumpuknya).

Dudung Darusman pernah menulis artikel tahun 1980-an yang merespon sebuah paper berjudul "Ekologi dan Ekonomi, Buah Simalakama" yang ditulis sesama rekan dosen Syafii Manan. Dalam pandangannya justru ekologi adalah landasan yang memberi konstrain terhadap ekonomi sehingga hubungan keduanya tidak harus seperti buah simalakama

\section{B. Pergeseran Paradigma}

Pada saat Dudung Darusman menuntut ilmu di Wisconsin, sudah sangat terasa di sana bahwa ketika orang berdiskusi tentang hutan, maka orang sudah tidak berbicara kayu semata. Tetapi lebih banyak manfaat yang lain dari hutan sebagai sumber daya yang bisa menyejahterakan masyarakat. Menurutnya di antara pemikir yang ada, baik dari akademisi, pembuat kebijakan maupun pelaksana kebijakan, pergeseran paradigma dari timber- 
based forest management ke communitybased forest management berkembang lebih dulu di universitas. Hal tersebut sudah dirasakannya ketika kuliah strata dua (S-2) program pascasarjana di Wisconsin.

Berbeda dengan para pemikir yang juga pembuat kebijakan era 90-an di Badan Perencanaan Pembangunan Nasional (Bappenas) yang sebagian besar masih berada di dalam wacana bagaimana membangun hutan kembali untuk memenuhi kebutuhan akan kayu baik domestik maupun ekspor. Menurutnya, seharusnyadipikirkan bagaimana dari hutan yang sama dapat menghasilkan produk yang beraneka ragam seperti tanaman obat, tata air, dan jasa lingkungan yang lain. Di Departemen Kehutanan (ketika wawancara dilakukan), keinginan politik sudah ada, tetapi menurutnya mindset personilnya masih tetap berorientasi kayu. Dudung Darusman merasa pembaharuan pemikiran di Departemen Kehutanan akan terjadi karena banyak personil Departemen Kehutanan yang menuntut ilmu untuk jenjang doktoral di IPB dan telah menunjukkan perubahan pemikiran yang transformatif.

Di tataran praktis, saat wawancara dilakukan, menurutnya peraturan dan perundangan yang ada sepertinya sudah ada yang mengakomodasi community-based forest management, tetapi mindset orangorang yang ada di "lapangan" masih belum berubah. Isu pergeseran paradigma mulai gencar disuarakan tahun 2000-an oleh Departemen Kehutanan tetapi implementasi di lapangan, masyarakat masih menjadi bagian pengelolaan hutan tetapi belum menjadi penentu pengelolaan hutan. Community-based forest management merupakan istilah dan gagasan yang berasal dari luar. Di Fakultas Kehutanan IPB, paradigma community-based forest management tertuang dalam pemikiran bahwa hutan merupakan kesatuan yang holistik di mana ada entitas masyarakat di sana yang harus menjadi pertimbangan dalam pengelolaan hutan.
Ketika mempelajari ilmu kehutanan untuk pertama kalinya di bangku kuliah, Dudung Darusman melihat memang ilmu kehutanan yang dibawa dari Jerman lebih banyak mengembangkan dan menekankan silvikultur (seni membangun hutan), ilmu yang mempelajari bagaimana struktur hutan agar hutan dapat menghasilkan kayu yang lestari, bila terjadi ketimpangan pada struktur hutan tersebut apa yang harus dilakukan sehingga menurut perspektif Dudung Darusman, nothing is wrong with forestry science as a science. Ketika hutan lestari dan menghasilkan produk hutan lestari yang menjadi pendapatan bagi negara, maka "beres" sudah ilmu kehutanan sampai di sana.

Pendistribusian pendapatan dari hutan oleh negara-lah yang saat ini menjadi masalah. Sebagai salah satu contohnya adalah ketika Dudung Darusman menjabat sebagai Dewan Pengawas (komisaris) Perum Perhutani, di mana menurutnya upah para pekerja upahan Perhutani masih sangat kecil nilainya. Pada masa jabatannya itu Dudung Darusman memperjuangkan peningkatan upah Perum Perhutani. Menurut perhitungannya, upah penyadap getah pinus yang diterima penyadap seharusnya bisa ditingkatkan hingga tiga kali lipat sementara Perhutani masih mendapat keuntungan berlipat ganda dari biaya yang dikeluarkan. Juga sistem bagi hasil yang saat ini diberlakukan di program Pengelolaan Hutan Berbasis Masyarakat (PHBM) yang dinilai lebih menguntungkan pihak Perum Perhutani daripada masyarakat. Tetapi menurutnya, hal itu merupakan keputusan struktur politik yang kolonialistik bukan keputusan ilmu kehutanan itu sendiri.

Seperti telah disebutkan, bahwa pada awalnya ilmu kehutanan yang dikembangkan di Fakultas Kehutanan IPB masih berbasis hutan sebagai penghasil kayu. Lulusan awal Fakultas Kehutanan yang bekerja di Perum Perhutani hanya mencari orang (pekerja upahan) untuk menanam, selesai menanam selesai sudah pekerjaan mereka. Menurut 
Dudung Darusman, bila ada pemberontakan, pencurian kayu, dan lain sebagainya, itu "bukan urusan" orang kehutanan tetapi menjadi urusan polisi. Namun ketika sampai di hutan/di lapangan, ketika orang kehutanan melihat realita masyarakat hutan yang miskin ingin berbuat banyak, tetapi mereka tidak dapat berbuat apa-apa karena mereka "terkungkung" oleh ilmu yang mereka dapat dan peraturan perundang-undangan yang ada.

Ketika situasi (politik) berubah dan muncul tuntutan-tuntutan masyarakat di bidang kehutanan, orang kehutanan (orang yang pernah menuntut ilmu kehutanan termasuk alumnus Fakultas Kehutanan IPB di dalamnya) ini sebenarnya ingin berubah tetapi tidak punya bekal ilmu (sosial) yang memadai dan belum dapat menentukan akan berubah "ke arah" mana, misalnya mereka tidak bisa memperbesar ongkos blandong (penebang pohon upahan) karena telah ada ketentuan Perum Perhutani yang berlaku saat itu.

Perkembangan ilmu pengetahuan kehutanan bukan merupakan masalah internal keilmiahan itu sendiri tetapi faktor eksternal juga menjadi penentu. Menurut Dudung Darusman, bahkan bila tidak ada pressure dari "luar", mungkin orang kehutanan hanya akan menjadi ahli-ahli ilmu hayati saja seperti silvikultur ataupun biologi yang akan mengembangkan pengaturan pertumbuhan dan pemanenan hutan lestari saja.

Dudung Darusman memberi satu contoh, yaitu ketika tahun 1962-1965 terjadi pergolakan politik di mana terjadi "perebutan lahan" dan "pencurian kayu" yang semakin lama semakin marak. Keadaan ini menurut Dudung Darusman dipercaya dipicu oleh miskinnya masyarakat yang tinggal di dalam dan di sekitar hutan. Diskusi panjang yang dia lalui sebagai pengajar tahun 1975 di lingkungan akademisi adalah sebuah pemikiran apakah masih menjadi tugas ilmu kehutanan, di mana harus bertanggung jawab pada kemiskinan masyarakat sekitar hutan yang berujung pada perambahan hutan? Bukankah hal itu seharusnya menjadi tanggung jawab penegak hukum?

Karena seperti telah disebutkan di atas, ketika orang yang berkecimpung di bidang kehutanan telah menghasilkan suatu produk untuk pendapatan negara, maka akan menjadi tanggung jawab sektor lainnya untuk mendistribusikannya dengan benar (merata) kepada masyarakat, termasuk masyarakat sekitar hutan. Bahkan juga berkembang diskusi bagaimana orang kehutanan dapat membangun hutan dengan baik bila "diganggu" terus? Namun ketika kinerja sektor lain (pendistribusi pendapatan negara dari hutan) tadi masih dipertanyakan, maka pertanyaan tersebut ("bagaimana orang kehutanan dapat membangun hutan dengan baik bila "diganggu" terus?") tidak harus dijawab.

Kemudian muncul gagasan bagaimana mengintegrasikan masyarakat sekitar hutan sehingga dapat hidup dengan sejahtera berdampingan dengan hutan. Oleh karena itu, 14 tahun semenjak berdirinya "Laboratorium Ekonomi Kehutanan" pada tahun 1979 yaitu ketika Herman Haeruman menjadi dekan, berubah menjadi "Laboratorium Sosial Ekonomi Kehutanan” pada tahun 1993 dengan Junus Kartasubrata sebagai pionir karena latar belakang ilmu sosialnya. Bapak Junus sebelumnya adalah pejabat di Perum Perhutani yang selalu menggeluti bidang kemasyarakatan.

\section{Universitas dan Pengetahuan sebagai "Legitimator"}

Dudung Darusman mengatakan, pemikiran dan perkataan rektor akan jauh lebih berharga untuk melegitimasi sesuatu dari pada pejabat negara yang lain. Pengajar di Fakultas Kehutanan sering diundang untuk menjadi pembicara di pertemuan-pertemuan tertentu seperti proses penyusunan peraturan perundang-undangan. Dudung Darusman seringkali mempunyai pandangan yang berbeda di dalam pertemuan-pertemuan 
tersebut. Menurutnya, rimbawan sejati adalah orang yang sangat spesial yaitu karena kecintaannya dengan hutan dan komitmennya terhadap kelestarian ada bukan hanya di dalam pikiran, tetapi ada di dalam hati. Hal ini dia rasakan bukan hanya pada rimbawan di Indonesia saja, tetapi ketika dia berkunjung ke Jerman maupun Korea, dia juga menemukan kenyataan yang sama ketika berbincang dengan rimbawan yang berasal dari negara tersebut.

Tapi sayangnya, menurutnya, secara ekonomi hutan tidak mempunyai produktivitas yang tinggi. Namun seorang Dudung Darusman hanya yakin dengan hati, bahwa hutan banyak manfaatnya untuk kehidupan. Dia merasa sebagai akademisi bidang kehutanan merasa terjepit oleh persekongkolan pada tingkat kebijakan ekonomi yang lebih tinggi antara negara dengan universitas yang pada kenyataannya yaitu antara kabinet negara dengan universitas tertentu.

Think tank kabinet di negara ini (konteks rezim orde baru) merupakan beberapa ekonom dari universitas tertentu yang mempunyai paham bahwa manfaat ekonomi dari hutan hanyalah yang berasal dari fungsi hutan yang tangible dan tidak melihat hutan sebagai suatu entitas yang juga mempunyai manfaat intangible, dan mereka berpihak kepada proses produksi dengan standar perusahaan besar. Mereka tidak suka berbicara tentang nasib petani-petani gurem dan orang miskin.

Pada tahun 1974, Food and Agriculture Organization (FAO) pernah menyarankan bahwa hutan dapat dikelola oleh badanbadan usaha baik yang kecil maupun yang besar. Tetapi keputusan "Jakarta" mengatakan bahwa pengelolaan 64 juta hektar hutan produksi harus berbentuk HPH (Hak Pengusahaan Hutan). Luas HPH terkecil 40.000-2.500.000 hektar. Hal ini dia rasakan sebagai keadaan yang menelikung akademisi untuk berpikir lebih luas. Jika berbicara tentang konsep hutan kemasyarakatan maka sangat bertentangan dengan konsep HPH.
Bagi para konseptor HPH, adalah bagaimana perusahaan yang besar dan hutan yang ada sesegera mungkin dapat menyumbangkan devisa sebagai penghasil kayu untuk ekspor, sehingga pemikiran tentang kehutanan masyarakat yang telah dirintis oleh para akademisi, pupus sudah.

Menteri-menteri Kehutanan yang berasal dari rimbawan sering terjepit dan "angkat tangan" dengan situasi politik kala itu hingga saat ini (frase "saat ini" merujuk pada waktu tahun 2008 ketika penelitian dilakukan). Maka kemudian muncul menterimenteri yang "non" kehutanan (tidak pernah mengenyam pendidikan ilmu kehutanan) yang menurutnya tidak mempunyai "benteng nurani" sebagai rimbawan, sehingga persekongkolan yang terjadi tidak sektoral kehutanan, melainkan kebijakan ekonomi secara keseluruhan. Mereka menjustifikasi pola pikir economic growth, big scale industry, dan bila masyarakat miskin kesulitan muncul kebijakan direct donation yang menurutnya konsep-konsep itu sangat bertentangan dengan pola pikir pemberdayaan masyarakat. Setelah berubahnya IPB sebagai BHMN (Badan Hukum Milik Negara), "orang-orang" yang duduk di majelis wali amanat yang ada sering dipertanyakan, apakah mereka mengerti tentang pertanian?

Berbicara kembali tentang scientific forestry yang muncul dan berkembang di Eropa, cocok untuk diterapkan di Eropa karena masyarakat mereka sudah lebih egaliter. Menurut Dudung Darusman, bila suatu badan negara telah bekerja dengan baik dan menghasilkan devisa bagi negara, maka negara telah mendistribusikan dengan baik kepada masyarakatnya, sehingga pembangunan infrastruktur baik dan jaminan sosial berjalan sebagaimana mestinya sehingga ketika sektor kehutanan akan mengekslusifkan diri tidak akan menjadi masalah. 


\section{Kembali ke "Istri Pertama" karena Idealisme}

Dudung Darusman pernah menjabat anggota Dewan Komisaris Perum Perhutani, di mana Dudung Darusman satu-satunya akademisi, dan Menteri Kehutanan kala itu adalah Djamaludin Suryohadikusumo (19931998) yang ingin menata kembali peran Perum Perhutani sebagai sumber devisa bagi negara. Diawali ketika Djamaludin sering membaca tulisan Dudung Darusman mengenai hutan yang dikuasai Perum Perhutani di Jawa sebenarnya bukan hanya penghasil kayu, namun juga sebagai penghasil jasa seperti air, lingkungan dan lain sebagainya yang nilainya dapat dirupiahkan. Beberapa gagasan dan kritik yang diajukan untuk Perum Perhutani ketika dia menjadi anggota Dewan Komisaris diantaranya 1) Bila Perum Perhutani akan beralih dan fokus untuk mengusahakan bidang jasa hutan seperti jasa air, lingkungan dan lain sebagainya maka produk kayu Perum Perhutani akan menjadi produk sampingan saja; 2) Sebagai produsen kayu jati terbesar di Indonesia pun, Perum Perhutani tidak dapat menentukan harga kayu sendiri. Harga kayu selama ini "dimainkan" oleh broker-broker yang bermain dalam lelang dan mereka inilah yang justru menikmati keuntungan yang besar. Bila ini dapat dibenahi, maka penghasilan Perum Perhutani akan meningkat. Hal ini telah berjalan sejak lama dan sepertinya sulit untuk diperbaiki karena ada struktur internal Perum Perhutani yang telah mendukung "permainan" ini; 3) Peningkatan tingkat upah/penghasilan bagi pekerja upahan Perum Perhutani seperti penyadap pinus, karena menurutnya bila masyarakat telah mendapat upah yang besar (seperti telah dipaparkan di atas) saat bekerja di hutan (dengan Perum Perhutani), maka dengan sendirinya masyarakat akan cinta terhadap hutannya sehingga hutan akan tetap terjaga; dan 4) Pemanfaatan intangible benefit hutan seperti jasa air dan jasa lingkungan sebagai pemasukan bagi Perum Perhutani. Seiring dengan berjalannya waktu, ketika keempat gagasan dan kritik kerja itu terus ia kembangkan, Menteri Kehutanan yang baru kala itu ingin mengembalikan Perum Perhutani "back to basic" sebagai produsen kayu saja. "Urusan pasar" bukan menjadi urusan Perum Perhutani karena terdapat struktur di dalam manajemen Perum Perhutani yang belum dapat berubah yang akhirnya menjadi tembok yang membatasi pengembangan ide-ide tersebut di atas. Tahun 1998 Dudung Darusman ditunjuk sebagai Staf Ahli Menteri Kehutanan bidang sosial ekonomi ketika Nurmahmudi Ismail menjabat sebagai Menteri Kehutanan. Ia bersedia ditunjuk karena ia ingin ikut ambil bagian dalam perbaikan kinerja Departemen Kehutanan.

Ketika bertugas terjadi perbedaan pandangan seorang Dudung Darusman dengan menteri terjadi yaitu ketika Nurmahmudi Ismail lebih memilih untuk mengejar pencuri kayu masa silam yang melibatkan "namanama besar", dan bukan mengejar pencuri kayu yang sedang melakukan aksinya. Kesibukan mengejar pencuri kayu itu pun menyebabkan hubungan antara pemerintah pusat dan pemerintah daerah yang saat itu masih dalam proses desentralisasi, menjadi terlantar. Menurutnya seharusnya desentralisasi kehutanan menjadi perhatian utama.

Desentralisasi di bidang kehutanan menurutnya tidak dapat dilepas begitu saja karena akan menjadi masalah yang sangat besar. Apalagi kebijakan perizinan pengusahaan kayu ratusan ribu hektar akhirnya juga menemui kegagalan. Konsep besar desentralisasi dalam benak Dudung Darusman adalah hutan lestari kabupaten maju tetapi daerah perlu terus dituntun atau diberi pengarahan bila arah improvisasi daerah menyimpang. Perbedaan pandangan tersebut menjadi alasan mengapa Dudung Darusman hanya menjabat tiga bulan saja, sehingga akhirnya ia memilih untuk kembali kepada "istri pertama" yaitu Fakultas Kehutanan IPB.

Dudung Darusman menjabat sebagai dekan untuk dua periode (1989-1996). 
Dengan jabatannya tersebut, Dudung Darusman banyak mencurahkan sumber daya baik tenaga pengajar dan yang lain, untuk pengembangan ilmu sosial ekonomi kehutanan. Tenaga pengajar bidang sosial ekonomi bertambah dari hanya empat menjadi 11 orang. Seperti telah disebutkan di atas, Laboratorium Ekonomi Kehutanan berubah menjadi Laboratorium Sosial Ekonomi Kehutanan adalah semasa Dudung Darusman menjabat sebagai dekan tepatnya tahun 1993. Pembangunan dan pengembangan keilmuan juga dilakukan pada Departemen Konservasi Sumber Daya Hutan (DKSH) karena menurutnya, DKSH-lah dalam waktu ke depan yang akan mengidentifikasi potensipotensi hutan baru yang dapat dikembangkan. Dalam rangka pengembangan ide tersebut di DKSH, Dudung menarik sumber daya tenaga pengajar dari disiplin selain kehutanan seperti biologi, kedokteran hewan maupun ilmu lingkungan dengan tujuan memperlebar horison bidang kehutanan itu sendiri.

\section{E. Pemikiran Kuhn, Falsifikasi Karl R. Popper, Revolusi Ilmu Pengetahuan Kehutanan dan Kelembaman Budaya: Kompleksitas Indonesia sebagai Masyarakat Pasca Kolonial (Post- Colonial Society)}

Modernitas dan teknologi mengarahkan manusia pada temuan-temuan baru dalam berbagai bidang (Beck \& Grande, 2010; Bhaskar, 2013; Dyke, 2006). Ilmu pengetahuan kian berkembang dan pemahaman manusia serta aplikasinya juga ikut menyesuaikan dengan perkembangannya. Tanpa ada pegangan dan landasan teoritis manusia akan terombang-ambing oleh perkembangan tersebut, terseret oleh masalah-masalah yang ada sebelum menemukan jawabannya. Agar hal tersebut tidak terjadi, Kuhn menawarkan sebuah solusi berupa konsep yang disebut sebagai paradigma (Grabowski \& Strzalka, 2009; Kindi, 2012; Preston, 2008). Dalam bahasa Inggris disebut paradigm dan bahasa
Perancis paradigme yang berarti contoh atau pola dasar yang luar biasa jelas, sedangkan dalam ranah filsafat secara khusus diartikan sebagai kerangka filosofis dan teoritis dalam disiplin atau aliran ilmu pengetahuan di mana teori-teori, hukum, serta generalisasi dan uji coba yang dilakukan dalam mendukungnya telah dirumuskan, baik yang mencakup segala kerangka filosofis maupun teoritis. Secara etimologis, Kuhn sendiri menjelaskan bahwa paradigma merupakan suatu cara pandang, nilai-nilai, metode-metode, prinsip dasar atau memecahkan sesuatu masalah yang dianut oleh suatu masyarakat ilmiah pada suatu tertentu (Kindi, 2012; Preston, 2008).

Pemikiran Kuhn tentang ilmu dan perkembangannya adalah respon terhadap pandangan positivisme dan pandangan Popper (Caldwell, 2010; Walker, 2010). Pengusung positivisme menganggap pengetahuan mengenai fakta obyektif merupakan pengetahuan yang benar dan secara umum mereka berpendapat bahwa sumber pengetahuan adalah pengalaman dan proses verifikasi serta konfirmasi (Khagram et al., 2010; Mingers, 2008). Sementara itu, Popper berpendapat bahwa proses perkembangan ilmu menurutnya harus berkemungkinan mengandung salah dengan proses yang disebut falsifikasi dan sanggahan (Diez, 2007; Rieppel, 2008). Meski terlihat berbeda, namun dua pendapat tersebut memiliki persamaan fundamental, yakni nuansa positivistik. Kuhn menolak pandangan tersebut dan menggunakan sejarah sebagai titik tolak penyelidikannya. Namun demikian, Kuhn menentang bahwa kemajuan keilmiahan dan perubahan paradigmanya merupakan "pengembangan lewat akumulasi" fakta-fakta dan teori-teori yang telah diterima. Dia berargumen bahwa kontinuitas itu diganggu oleh periode-periode kemunculan ilmu pengetahuan yang bersifat revolusioner. Penemuan "anomali" selama revolusi sains memunculkan paradigma baru (Anderson et al., 2010; Gleick, 2011; Kuhn, 1996). 
Paradigma tersebut kemudian mengajukan pertanyaan-pertanyaan baru dari data yang lama, bergerak di luar "penyelesaian teka teki" dalam paradigma sebelumnya, mengubah aturan main dan "peta" yang mengarahkan kepada penelitian baru. Keyakinan Kuhn bahwa pergeseran paradigma adalah percampuran sosiologi, antusiasme, dan janji ilmiah, dan bukan prosedur yang ditentukan secara logis ini memicu kegemparan (Fuller, 2009). Kuhn menjawab permasalahan ini dalam tulisan yang diterbitkan dalam edisi kedua pada tahun 1969. Bagi beberapa komentator, pemikiran Kuhn telah memperkenalkan humanisme realistik dalam inti sains, sementara yang lain merasa sains dirusak oleh unsur-unsur irasional yang dimasukkan oleh Kuhn (Bernstein, 2011).

Ilmu pengetahuan kehutanan awal yang berkembang di Indonesia berasal dari Jerman dikenal sebagai Germany scientific forestry (scientific forestry) yang digunakan sebagai dasar ilmiah oleh kolonial untuk membangun hutan di Indonesia, diadopsi pula dalam "suasana" yang kolonial oleh institusi negara Indonesia yang mengurusi kehutanan untuk pertama kali. Scientific forestry merupakan bentuk pengelolaan sumber daya hutan yang mengedepankan perhitungan rasional bagaimana satu bentang lahan hutan menghasilkan produksi kayu secara lestari di dalam ruang yang hampa dari kehidupan sosial. Scientific forestry, di negara asalnya, dihasilkan dari konteks sosial di mana telah terjadi pemagaran (disclosure) lahan yang dikuasai negara dan tuan-tuan tanah (landlords) yang sama sekali berbeda dengan konteks sosial di Indonesia di mana lahan pada awalnya dikuasai secara komunal (Mancini, 2008; Murray Li, 2007; Yasmi, Guernier, \& Colfer, 2009). Pada praksisnya, di Indonesia, scientific forestry sangat sesuai dikembangkan untuk menunjang penguasaan komoditas dan teknologi oleh negara terhadap sumber daya hutan pada awal-awal pemerintahan Indonesia terbentuk. Manifestasi politik Orde Baru yang merupakan perwujudan kolonialisme dalam bentuk lain (Tjondronegoro \& Wiradi, 2008), memberikan ruang yang luas terhadap reproduksi pengetahuan scientific forestry untuk menciptakan tenaga-tenaga terampil di bidang kehutanan yang mempunyai konformitas tinggi terhadap semangat supremasi produksi kayu dari hutan sebagai modal pembangunan. Scientific forestry menjadi sesuatu yang birokratis dan dianggap menjadi sebuah paradigma ilmu pengetahuan yang sah yang melambari praktik pengelolaan kehutanan di Indonesia.Scientificforestry yang membutuhkan peralatan teknis (peraturan dan kebijakan) untuk dapat diterapkan di lapangan yang disusun oleh para rimbawan dalam konformitas yang tinggi pada sentralisasi politik dan kekuasaan. Strukturasi dialektika tersebut berevolusi menjadi nilai (value) dan budaya (culture) para rimbawan kala itu yang tidak hanya menduduki jabatan pada pemerintahan tetapi yang memilih menjadi analis dan praktisi di bidang kehutanan dan lingkungan hidup. Sifat sentralisasi yang dipraktikkan rezim Orde Baru bukan saja memusatkan wewenang penyusunan keputusan dan kebijakan namun juga pemusatan hasil eksploitasi kekayaan alam. Orde Baru adalah rezim yang paling besar menuai kritik atas sifat tersebut terlebih pada distribusi belanja negara yang terkait tidak meratanya pembangunan dan penguasaan alatalat produksi dan kekayaan alam yang hanya diberikan kepada orang-orang yang berada di sekitar pusat kekuasaan. Implikasinya di bidang kehutanan yang sangat kentara adalah marginalisasi komunal-komunal yang selama ini hidup "dengan" hutan dan tidak adanya reinvestasi hijau di mana hasil eksploitasi kayu dan hasil hutan lainnya sebagian besar tidak kembali kepada usaha-usaha perbaikan hutan dan kesejahteraan komunal-komunal yang menjadi terasing di tanahnya sendiri.

Perlawanan atas praktik kekuasaan Orde Baru yang menyuarakan keadilan atas kapitalisme dan liberalisme tersebut 
berimplikasi banyak pada ilmu pengetahuan kehutanan (Handoyo, 2008). Perlawanan tersebut mengadvokasi supremasi sipil atas common property. Alat-alat produksi yang dikuasai segelintir taipan dituntut dikembalikan ke atas pangkuan komunal. Hembusan perspektif community-based forest management dan tuntutannya agar dapat diaplikasikan di lapangan menjadi suara perlawanan yang hingga saat ini bisa dirasakan. Seperti tersebut pada bab sebelumnya, bagi seorang Dudung Darusman nothing is wrong with scientific forestry as a science, ketika hutan lestari dan menghasilkan produk hutan yang lestari pula yang menjadi pendapatan bagi negara, maka "beres" sudah ilmu kehutanan sampai di sana. Profesor Dudung Darusman berpendapat pendistribusian pendapatan negara dari hutanlah yang menjadi masalah terbesar di bidang kehutanan di negeri ini. Selanjutnya, ketika kas negara yang berasal dari hutan sebagian didistribusikan kepada komunal-komunal yang terkena dampak aplikasi scientific forestry secara adil dan proporsional sebenarnya perlawanan itu tidak akan pernah muncul. Perspektif communitybased forest management kemudian dengan serta merta ditasbihkan secara ilmiah menjadi sebuah paradigma baru pengelolaan hutan yang dianggap mampu mengemban tugas tegaknya keadilan dalam proses pembangunan hutan dan lingkungan yang sudah porakporanda. Perspektif tersebut dianggap ampuh menanggulangi ketimpangan distribusi alat produksi dan hasil eksploitasi hasil hutan.

Persepektif Kuhnian tidak setuju atas kemajuan keilmiahan dan perubahan paradigmanya merupakan "pengembangan lewat akumulasi" fakta-fakta dan teoriteori yang telah diterima. Kuhn berargumen bahwa kontinuitas itu diganggu oleh periodeperiode kemunculan ilmu pengetahuan yang bersifat revolusioner (Sijuwade, 2007). Penemuan "anomali" selama revolusi sains memunculkan paradigma baru. Menurut penulis, atas perspektif Kuhn dan pandangan
Dudung Darusman, community-based forest management tidak memenuhi syarat untuk ditasbihkan sebagai paradigma baru di dalam ranah ilmu pengetahuan kehutanan. Perpindahan paradigma ilmu pengetahuan disyaratkan oleh Kuhn dapat terjadi melalui beberapa tahap (Dankwa-Mullan et al., 2010; Greiffenhagen \& Sherman, 2008; Khuza, 2013; Shepherd \& Challenger, 2013; Spangenberg, 2011). Tahap pertama, tahap pra-ilmiah dan pra-paradigma, di mana tidak ada konsensus tentang teori apapun. Fase ini umumnya ditandai oleh beberapa teori yang tidak sesuai dan tidak lengkap hingga akhirnya salah satu dari teori ini "menang." Hal semacam ini berlangsung selama kurun waktu tertentu sampai suatu paradigma tunggal diterima oleh semua, sehingga jalan menuju normal science mulai ditemukan. Tahap kedua, sains normal. Dalam fase ini seorang ilmuwan mengumpulkan banyak teori layaknya kepingan puzzle. Dalam sains normal, tugas ilmuwan memperluas dan lebih membenarkan paradigma. Dalam wilayah ini bisa saja terdapat banyak persoalan yang tidak terselesaikan dan kejanggalan, Kuhn menyebut keadaan ini sebagai anomali. Jika anomali-anomali yang ada terakumulasi dan menjadi akut, maka akan menimbulkan krisis dan memicu timbulnya paradigma baru, inilah yang oleh Kuhn disebut sebagai "revolusi sains". Tahap ketiga, yakni pergeseran paradigma. Pada periode revolusioner ini suatu komunitas ilmiah menyusun diri kembali di sekeliling suatu paradigma baru, memilih nilai-nilai, norma-norma, asumsi-asumsi, bahasa-bahasa, dan cara-cara mengamati serta memahami alam ilmiahnya dengan cara yang baru. Inilah proses pergeseran paradigma (shifting paradigm), yakni proses dari keadaan sains normal menuju sains revolusi. Cara pemahaman dan pemecahan persoalan model lama ditinggalkan dan berganti dengan yang baru. Kuhn percaya bahwa semua bidang ilmiah melalui pergeseran paradigma ini berkali-kali yang disebut extraordinary 
science (sains luar biasa), seperti teori-teori baru menggantikan yang lama (Bird, 2012; Collins, 2012; Rowbottom, 2011).

Tidak ada masalah internal yang paradigmatik yang melanda scientific forestry sebagai sebuah paradigma. Scientific forestry belum diuji atas ketidakmampuannya menjawab pertanyaan-pertanyaan yang bersifat internal paradigmatik misalnya kendala-kendala silvikulturistik dalam membangun hutan. Tenggelam dalam hiruk pikuk perlawanan atas keadilan yang kemudian membuat alat ujinya bias, yaitu mampu tidaknya scientific forestry menjawab gangguan-gangguan membangun hutan yang timbul dari perlawanan ketidakadilan dan ketidakamanahannya negara dalam hal distribusi hasil hutan. Scientific forestry tenggelam oleh orkestrasi praktik kekuasaan dan politikyang partikularserta manifestasinya dalam pengelolaan hutan nasional yang lebih bersifat eksternal paradigmatik. Menurut penulis community-based forest management bahkan global-based forest management yang dipaksakan bersifat ilmiah sebagai paradigma pengganti dan dipercaya menyetir pengelolaan hutan di Indonesia, tidak akan menyelesaikan persoalan kehutanan dan lingkungan hidup di Indonesia ketika keinginan politik atas penegakan keadilan dan supremasi sipil/ komunal atas common property masih jauh panggang dari api.

\section{KESIMPULAN DAN SARAN}

\section{A. Kesimpulan}

Atas tawaran Kuhn dan argumen Dudung Darusman sebagai sebuah perspektif, community-based forest management tidak dapat disebut sebagai sebuah paradigma baru yang menggantikan paradigma scientific forestry. Proses perubahan dan perpindahan perspektif dalam keilmuan kehutanan di Indonesia tidak dapat dianggap sebagai sebuah revolusi keilmuan yang mensyaratkan perubahan paradima. Orkestrasi praktik kekuasaan dan politik yang partikular serta manifestasinya dalam pengelolaan hutan nasional yang lebih bersifat eksternal paradigmatik bertanggung jawab atas bias keilmiahan tersebut.

\section{B. Saran}

Orkestrasi praktik kekuasaan dan politik dalam beberapa dekade terakhir telah membuat "generic scientific forestry" menjadi sulit atau tidak bisa diterapkan lagi. Oleh karena itu, perlu dikembangkan advanced scientific forestry (enriched by community based-forestry management).

\section{UCAPAN TERIMA KASIH (ACKNOWLEDGEMENT)}

Penulis mengucapkan terima kasih yang tak terhingga kepada Prof. Dr. Ir. Dudung Darusman, M.Sc yang telah bersedia menjadi narasumber utama dalam tulisan ini. Terima kasih kepada Kepala Pusat Penelitian Pengembangan Sosial, Ekonomi, Kebijakan, dan Perubahan Iklim atas dukungannya dalam penulisan karya tulis ilmiah (KTI) ini. Terima kasih kepada Ford Foundation Ensopro (Environmental Sociology Project) - Fakultas Ilmu Sosial dan Politik (FISIP) Universitas Indonesia atas dukungan pendanaan dalam mewujudkan KTI ini.

\section{DAFTAR PUSTAKA}

Anderson, M., Deely, J., Krampen, M., Ransdell, J., Sebeok, T. A., \& von Uexküll, T. (2010). A semiotic perspective on the sciences: Steps toward a new paradigm1. Essential Readings in Biosemiotics: Anthology and Commentary, 3, 377 .

Beck, U., \& Grande, E. (2010). Varieties of second modernity: The cosmopolitan turn in social and political theory and research. The British Journal of Sociology, 61(3), 409-443.

Bernstein, R. J. (2011). Beyond objectivism and relativism: Science, hermeneutics, and praxis. Philadelphia: University of Pennsylvania Press.

Bertaux, D. (1981). Biography and society: The life history approach in the social sciences. London: Sage. 
Bhaskar, R. (2013). A realist theory of science. London: Routledge.

Bird, A. (2012). 10 Kuhn, naturalism, and the social study of science. Kuhn's The Structure of Scientific Revolutions Revisited, 12, 205.

Bourdieu, P. (1991). Pierre - The Peculiar History of Scientific Reason. Sociological Forum, 6(1), 3-26.

Caldwell, B. (2010). Beyond positivism. London: Routledge.

Campbell, M. S. (1999). Using a life history approach to explore the identity of a woman diagnosed with Alzheimer's disease: The life of Mary. (Thesis). Blacksburg: Faculty of the Virginia Polytechnic Institute and State University

Chamberlayne, P., Bornat, J., \& Wengraf, T. (2000). The turn to biographical methods in social sciences. London, UK: Routledge.

Collins, H. (2012). Comment on Kuhn. Social Studies of Science, 42(3), 420-423.

Creswell, J. W., \& Poth, C. N. (2017). Qualitative inquiry and research design: Choosing among five approaches. London: Sage publications.

Creswell, W. J. (2003). Research design : Qualitative, quantitative and mixed methods approaches. ( $3^{\text {rd }}$ ed.). London: SAGE.

Dankwa-Mullan, I., Rhee, K. B., Stoff, D. M., Pohlhaus, J. R., Sy, F. S., Stinson Jr, N., \& Ruffin, J. (2010). Moving toward paradigmshifting research in health disparities through translational, transformational, and transdisciplinary approaches. American Journal of Public Health, 100(S1), S19--S24.

Diez, J. (2007). Falsificationism and the structure of theories: The Popper? Kuhn controversy about the rationality of normal science. Studies in History and Philosophy of Science Part A, 38(3), 543-554. https://doi.org/10.1016/j. shpsa.2007.06.007

Dyke, M. (2006). The role of the "other"in reflection, knowledge formation and action in a late modernity. International Journal of Lifelong Education, 25(2), 105-123.

Flick, U. (2014). An introduction to qualitative research. London: Sage.

Fuller, S. (2009). Knowledge politics and new converging technologies: A social epistemological perspective. Innovation: The European Journal of Social Science Research, 22(1), 7-34. https://doi. org/10.1080/13511610902770552.

Gleick, J. (2011). Chaos: Making a new science. (Enhanced Edition). New York: Viking Books.
Grabowski, F., \& Strzalka, D. (2009). Conception of paradigms evolution in science-towards the complex systems approach. Egitania Sciencia, (4), 197.

Greiffenhagen, C., \& Sherman, W. (2008). Kuhn and conceptual change: On the analogy between conceptual changes in science and children. Science \& Education, 17(1), 1-26. https://doi. org/10.1007/s11191-006-9063-5

Handoyo. (2008). Scientific forestry community-based forest management perubahan paradigmatik ke sebuah critical discourse analysis pendekatan pada buku pengajaran "pengantar ilmu kehutanan". Jurnal Penelitian Sosial dan Ekonomi Kehutanan, 5(3).

Khagram, S., Nicholas, K. A., Bever, D. M., Warren, J., Richards, E. H., Oleson, K., ... Brauman, K. A. (2010). Thinking about knowing: Conceptual foundations for interdisciplinary environmental research. Environmental Conservation, 37(4), 388-397. https://doi.org/10.1017/ S0376892910000809.

Khuza, M. (2013). Kuhn: Pergeseran paradigma dan revolusi ilmu. (Makalah disampaikan sebagai tugas materi kuliah Filsafat Ilmu yang diampuh Muhammad Muslih, MA. (Selasa, 21 Mei 2013)). Gontor: Program Pascasarjana Institut Studi Islam Darussalam (ISID) GONTOR.

Kindi, V. (2012). Kuhn's paradigms. Kuhn's The Structure of Scientific Revolutions Revisited, 91-111.

Kuhn, T. S. (1996). The structure of scientific revolutions. ( $3^{\text {rd }}$ ed). Chicago: University of Chicago Press.

Mancini, L. (2008). Horizontal inequality and communal violence: Evidence from Indonesian Districts. In F. Stewart (Ed.). Horizontal inequalities and conflict: Understanding Group violence in multiethnic societies (pp. 106-135). London: Palgrave Macmillan UK. https://doi. org/10.1057/9780230582729_6.

Marshall, P., \& Hurworth, R. (2009). Mediation and qualitative research interviewing: Commonality and difference. ADR Bulletin, 11(7), 2.

Michon, G., De Foresta, H., Levang, P., \& Verdeaux, F. (2007). Domestic forests: A new paradigm for integrating local communities' forestry into tropical forest science. Ecology and Society, 12(2).

Mingers, J. (2008). Management knowledge and knowledge management: Realism and forms of truth. Knowledge Management Research \& Practice, 6(1), 62-76. https://doi.org/10.1057/ palgrave.kmrp.8500161. 
Murray Li, T. (2007). Practices of assemblage and community forest management. Economy and Society, 36(2), 263-293. https://doi. org/10.1080/03085140701254308.

Peluso, N. L. (1994). Rich forests, poor people: Resource control and resistance in Java. Berkeley: University of California.

Preston, J. (2008). Kuhn's' the structure of scientific revolutions': A reader's guide. New York: Bloomsbury Publishing.

Purtill, R. L. (1967). Kuhn on scientific revolutions. Philosophy of Science, 34(1), 53-58.

Rieppel, O. (2008). Re-writing Popper's philosophy of science for systematics. History and Philosophy of the Life Sciences, 293-316.

Roshetko, J. M., Snelder, D. J., Lasco, R. D., \& Van Noordwijk, M. (2008). Future challenge: A paradigm shift in the forestry sector. In D.J. Snelder \& R.D. Lasco. Smallholder tree growing for rural development and environmental services: Lessons from Asia (pp. 453-485). Dordrecht: Springer.

Rowbottom, D. P. (2011). Kuhn vs. Popper on criticism and dogmatism in science: A resolution at the group level. Studies in History and Philosophy of Science Part A, 42(1), 117-124.

Shepherd, C., \& Challenger, R. (2013). Revisiting paradigm(s) in management research: A rhetorical analysis of the paradigm wars. International Journal of Management Reviews, 15(2), 225-244. https://doi.org/10.1111/ ijmr. 12004 .
Sijuwade, P. O. (2007). Recent trends in the philosophy of science: Lessons for sociology. Journal of Social Sciences, 14(1), 53-64.

Silverman, D. (2013). Doing qualitative research: A practical handbook. London: SAGE Publications Limited.

Spangenberg, J. H. (2011). Sustainability science: A review, an analysis and some empirical lessons. Environmental Conservation, 38(3), 275-287.

Tjondronegoro, S. M. P., \& Wiradi, G. (2008). Dua abad penguasaan tanah: Pola penguasaan tanah pertanian di Jawa dari masa ke masa. (S. M. P. Tjondronegoro \& G. Wiradi, Eds.). Jakarta: Yayasan Obor Indonesia.

van Noordwijk, M., Mulyoutami, E., Sakuntaladewi, N., \& Agus, F. (2008). Swiddens in transition: Shifted perceptions on shifting cultivators in Indonesia. Occasional Paper, (9).

Walker, T. C. (2010). The perils of paradigm mentalities: Revisiting Kuhn, Lakatos, and Popper. Perspectives on Politics, 8(2), 433-451.

Yasmi, Y., Guernier, J., \& C.J.P. Colfer. (2009). Positive and negative aspects of forestry conflict: Lessons from a decentralized forest management in Indonesia. International Forestry Review, 11(1), 98-110. 
Jurnal Penelitian Sosial dan Ekonomi Kehutanan Vol. 15 No.1, 2018 